\title{
FEATURES OF USE OF FLEXIBLE METHODS \\ OF TEACHING OF STUDENTS OF INCLUSIVE CLASSES
}

\section{ОСОБЛИВОСТІ ВИКОРИСТАННЯ ГНУЧКИХ МЕТОДІВ НАВЧАННЯ УЧНІВ ІНКЛЮЗИВНИХ КЛАСІВ}

\section{Aksyonova Olena ${ }^{1}$ \\ Pivnenko Yuliya ${ }^{2}$}

DOI: http://dx.doi.org/10.30525/978-9934-571-27-5_1

\begin{abstract}
The article foresees the potential negative consequences of existing pedagogical practice of teaching subjects in an inclusive class basing on the survey of various positions concerning inclusive education. The analysis of the experience of teachers has showed that the majority of attempts to modernize the methodology of subjects of the educational branch "Health and Physical Culture" are based on outdated techniques of "hanging the labels", authoritarian approach, artificial restraint or enforcement.

Today teachers work in the state of functioning of different contradictions, among which, according to the authors, the priority one is the following: between the need to increase the Inclusion Index of their class, educational institution and the lack of appropriate methodological tools that would allow to carry out effectively the training program with all the students of the inclusive class.

The purpose of the research is to develop and test experimentally the efficiency of the matrix of joint teaching tasks for the students of inclusive classes.

The subject of the research is the methodology of teaching the subjects "Health Basics", "Physical Culture" in inclusive classes.
\end{abstract}

\footnotetext{
${ }^{1}$ Candidate of Pedagogical Sciences, Associate Professor, Head of the Department of Rehabilitation Pedagogy and Healthy Lifestyle, Municipal Institution "Zaporizkyi Regional Institute of Postgraduate Studies of Pedagogical Education" of Zaporizhzhya Regional Council, Ukraine ${ }^{2}$ Candidate of Pedagogical Sciences, Associate Professor of the Department of Rehabilitation Pedagogy and Healthy Lifestyle, Municipal Institution "Zaporizkyi Regional Institute of Postgraduate Studies of Pedagogical Education" of Zaporizhzhya Regional Council, Ukraine 
The objectives of the study: on the basis of the survey of the various positions on inclusive education to predict possible negative consequences of the existing pedagogical practice of teaching subjects in the inclusive class; to compare in the didactic lines the components of the purpose, pedagogical tasks, principles of inclusive education with methodical techniques at the lessons of the educational branch "Health and Physical Culture"; focusing on perspective aspects of humanitarian technologies to develop the matrix of common educational tasks for students of inclusive classes.

The authors have allocated five didactic lines: independence; vital knowledge and skills; healthy lifestyle; safe behavior; harmony with the environment. Matrix of common learning tasks for students of inclusive classes is structured according to the following components: didactic lines; benefits for students with special educational needs (indicated respectively to each didactic line); benefits for neurotic students; algorithm of the development of educational tasks for students.

The authors give examples of educational tasks for students according to the didactic lines; they have identified key competencies to the formation of which each educational task is directed.

The research made it possible to state the following: attempts of modern teachers to modernize the teaching methods at the Educational branch "Health and Physical Culture" in inclusive classes are fragmentary and do not have a systematized format. Most of them are based on outdated techniques of "hanging the labels", authoritarian approach, artificial restraint or enforcement; the analysis of tasks from the educational programs for the subjects "Health Basics", "Physical Culture", the comparison of their essential direction with the principles of inclusive education have allowed to develop the matrix of common educational tasks for students of inclusive classes; the experimental testing of educational tasks have provided the opportunities to indicate their high coefficient of effectiveness not only in the conditions of inclusive training, but also in ordinary classes.

\section{1. Вступ}

Поняття «інклюзія», «інклюзивна освіта», «клас 3 інклюзивною формою навчання» поступово опановують розум і душі усіх представників педагогічної спільноти. Дитина 3 обмеженими можливостями це особлива людина зі своїми поглядами, своїми бажаннями, своїм почуттям людської гідності. Діти з обмеженими можливостями, які не 
мають відхилень у психічному розвитку, повинні отримувати повноцінну загальну освіту, а їхнє соціальне життя має оптимально наближатися до життя повноцінної людини. Саме такому гуманістичному напряму розвитку надає перевагу освітня політика України останні роки, орієнтуючись на базову доктрину Організації Об'єднаних Націй.

Зазначений напрям державних реформ, безумовно, актуальний i для педагогів освітньої галузі «Здоров’я та фізична культура».

Однак, аналіз досвіду роботи учителів навчальних предметів «Основи здоров'я» $\mathrm{i}$ «Фізична культура», які працюють в інклюзивних класах, дозволив констатувати, що питання про відкритість і доступність освіти, навчання без бар'єрів до сьогодні ще залишається проблемним.

Сучасними дослідженнями різних авторів відтворено цілісну картину впливу різноманітних факторів на розвиток інклюзивної освіти в Україні. Серед найбільш впливових факторів - фінансове, нормативно-правове, методичне та дидактичне забезпечення інклюзивної освіти. Отже, учителі сьогодні працюють у стані функціонування різних суперечностей, серед яких пріоритетною, на нашу думку, є така: між потребою підвищення Індексу інклюзії свого класу, навчального закладу та відсутністю відповідного методичного інструментарію, який би дозволив при цьому ефективно виконувати навчальну програму з усіма учнями інклюзивного класу [4].

Саме тому сучасному учителю, який працює в інклюзивному класі, вкрай важливо мати чіткий інструментарій щодо наступних позицій:

- відбір навчального матеріалу, який би відповідав можливостям та інтересам усіх учнів;

- подолання труднощів спілкування між усіма учасниками навчального процесу;

- усунення (профілактика) психологічних забобонів;

- виконання вимог до безпечної роботи усіх учнів;

- виконання програмних вимог до сучасного уроку.

За висновками різних авторів, є певні бар'єри щодо розвитку інклюзивної освіти. Зокрема, більшість педагогів не розуміють сутність інклюзивної освіти; не володіють грунтовними знаннями про вікові та психофізичні особливості учнів з різними патологіями розвитку; не мають навичок щодо створення конструктивної взаємодії між різними учасниками навчального процесу. Найбільш суттєвий бар'єр - органі- 
зація та практика навчального процесу, застарілі негнучкі методи навчання, які на сьогодні існують в освіті. Слід модернізувати навчальний процес на засадах нових педагогічних підходів, які дозволять ураховувати найбільш повно особливі освітні потреби кожного учня.

Зазначені суперечності та потреби практики обумовили актуальність теми статті.

Мета дослідження - розробити та експериментально перевірити ефективність матриці спільних навчальних завдань для учнів інклюзивних класів.

\section{Завдання дослідження:}

1) на основі оглядового ознайомлення з різними позиціями щодо інклюзивного навчання спрогнозувати можливі негативні наслідки наявної педагогічної практики викладання навчальних предметів у інклюзивному класі;

2) зіставити в дидактичні лінії складові мети, педагогічних завдань, принципів інклюзивного навчання з методичними прийомами на уроках освітньої галузі «Здоров’я та фізична культура»;

3) орієнтуючись на перспективні аспекти гуманітарних технологій роз-робити матрицю спільних навчальних завдань для учнів інклюзивних класів.

Методологічне та загальнонаукове значення. На основі оглядового ознайомлення з різними позиціями щодо інклюзивного навчання спрогнозовані можливі негативні наслідки наявної педагогічної практики викладання навчальних предметів в інклюзивному класі. Маючи підгрунтя - гуманітарні технології - розроблена матриця спільних навчальних завдань для учнів інклюзивних класів.

Дослідження здійснювалося в контексті науково-методичної проблеми кафедри реабілітаційної педагогіки та здорового способу життя Запорізького обласного інституту післядипломної педагогічної освіти «Розвиток професійної компетентності суб'єктів корекційно-реабілітаційного освітнього процесу в системі неперервної освіти».

\section{2. Інклюзія - крок до толерантності}

«Інклюзія - це доведений українською практикою крок до виховання толерантності як у дітей, так і у дорослих. Інклюзивна освіта це не мода, а вимога часу, і їі необхідно впроваджувати, але не поспішати, аби не забалакати і не сплюндрувати ідею» [5, с. 16]. 
Сучасні дослідники по різному інтерпретують ключові поняття, які пов'язані з інклюзивною освітою. В контексті теми теоретичного дослідження підтримуємо такі позиції:

- інклюзія - відсутність бар'єрів між різними дітьми [6];» ...постійний пошук ефективніших шляхів задоволення індивідуальних потреб усіх дітей [9];

- інклюзивна освіта - сприймає дитину такою, яка вона є; підбудовує систему освіти під цю дитину [1];

- інклюзивний підхід - створення таких умов, за яких «...усі учні мають однаковий доступ до освіти...; водночас усі учні мають можливість отримати досвід, знання, що сприяють подоланню упереджень і дискримінації та забезпечують формування позитивного ставлення до тих, хто «відрізняється» [1]; «...у цьому випадку відмінності розглядаються як позитивне явище, яке стимулює навчання дітей та дорослих» [5].

Індекс інклюзії зосереджує увагу педагогів на командних діях. Йдеться перш за все про альянс для інклюзивного розвитку освіти [1], який узгоджує зусилля всіх учасників освітнього процесу, координує їхні ініціативи щодо навчання здоровому способу життя; усунення обмежень; забезпечення всебічної освіти; боротьбу з дискримінацією; сталий розвиток; відмову від насильства; співпрацю; громадянство світу; демократизацію.

Існує декілька моделей включення в освітній процес дітей з особливими освітніми потребами.

1. До класу приймаються 1-2 дитини з інвалідністю. Вони разом зі своїми однолітками навчаються із супроводом вузьких спеціалістів.

2. У навчальному закладі створені спеціальні класи для дітей з особли-вими освітніми потребами; загальноосвітні класи, в яких навчаються діти з особливими освітніми потребами; практикується також проведення певної частини уроку, на якій перебувають в тому числі діти з особливими освітніми потребами.

Обидві моделі вже мають позитивний ефект: підвищення рівня задоволеності освітнім процесом з боку батьків та інтересу до досягнень своєї дитини.

\section{3. Методичне та дидактичне забезпечення інклюзивної освіти}

Педагогічна думка зосереджена на чітких діях стосовно ефективного впровадження інклюзивної освіти в Україні [4, с. 29]. Виокремлюємо такі: 
- не копіювати бездумно іноземний досвід, а вивчити свій та застосовувати все найкраще, що вже існує у вітчизняній педагогічній практиці;

- забезпечувати розробку навчальних і методичних матеріалів не на засадах розмежування способів роботи з учнями з різними особливостями розвитку, а їхньої інтеграції.

Досвід роботи вчителів освітньої галузі «Здоров'я та фізична культура»

Існує вже певний досвід роботи вчителів освітньої галузі «Здоров'я та фізична культура» в інклюзивних класах. Зупинимося на деяких $з$ них.

Метод реальної інклюзії для соціальної адаптації (РІСА, Україна) - адаптований під ігровий простір; передбачає соціальну адаптацію дитини в колі нейротипічних дітей за допомогою ігрових прийомів (створюється прообраз майбутньої системи взаємодії [9].

«3С-Терапія». Автор - Пол Кожокару (Румунія). (Prof. Paul Constantin Cojocaru-Founder 3C Therapy-Psychomotor Autistic Therapy (P.A.T.). Складається 3 трьох взаємопов'язаних частин: перша consciousness- розвиток координації в просторі та часі, узгодженість рухів; друга - coordination - удосконалення усвідомленості рухових дій; планування рухів на перспективу; моторне мислення; третя concentration - розвиток комунікативних навичок [7; 8].

Інклюзивний підхід на уроках фізичної культури. Автор - Палій Лариса (Росія). Передбачає включення до програми спеціальних розділів (модулів) для дітей з обмеженими можливостями здоров'я; систематизацію певних рухових дій (комплексів вправ) з урахуванням нозології різних груп дітей; варіативність рухової та практичної діяльності; виконання рухових завдань невеликими порціями; використання цікавого, яскравого інвентарю та обладнання; використання засобів щодо активізації пізнавального інтересу дітей (ІКТ; картки; тренінгові вправи; психогімнастика; релаксація тощо) [14].

Ми виокремили найбільш рентабельні організаційно-методичні позиції, які використовуються в перспективній практиці інклюзивної освіти:

- проблемно-пошуковий метод передбачає соціальну взаємодію різних суб'єктів навчального процесу під час дослідження та пошуку певних шляхів вирішення завдання; 
- колове розташування навчальних місць у групі посилює ефект спілкування іiї учасників;

- використання роздаткового матеріалу, зміст і оформлення якого стимулює учнів на активну діяльність;

- використання індивідуальних критеріїв і показників щодо алгоритму дій різних учнів, а також до оцінювання відносної успішності дитини.

Усі зазначені вище складові досвіду різних авторів мають право на існування в інклюзивному освітньому просторі. Однак, у кожному $є$ певні недоліки (табл. 1), для подолання яких слід шукати конкретні шляхи.

Таблиця 1

Недоліки щодо вузького використання певних технологій, методик, прийомів на уроках «Основи здоров'я», «Фізична культура»

\begin{tabular}{|l|l|}
\hline \multicolumn{1}{|c|}{ СКЛАДОВА дОСВІДу } & \multicolumn{1}{|c|}{$\begin{array}{c}\text { МОжЛИВІ НЕГАТИВНІ } \\
\text { НАСЛІДКИ }\end{array}$} \\
\hline $\begin{array}{l}\text { Використання ІКТ, тренінгових вправ, } \\
\text { карток }\end{array}$ & $\begin{array}{l}\text { Порушення вимог до регулювання } \\
\text { фізичного та психоемоційного наван- } \\
\text { таження учнів }\end{array}$ \\
\hline $\begin{array}{l}\text { Використання конкретних реабілітаці- } \\
\text { йних методик для певної нозологічної } \\
\text { групи захворювань }\end{array}$ & $\begin{array}{l}\text { Зниження інтересу і активності учнів, } \\
\text { які не мають таких відхилень у стані } \\
\text { здоров'я }\end{array}$ \\
\hline $\begin{array}{l}\text { Розподіл учнів на типологічні групи } \\
\text { без їнього бажання, не залежно від } \\
\text { іхнього стану, самопочуття, рівня } \\
\text { учнівських досягнень }\end{array}$ & $\begin{array}{l}\text { Є негуманним, некоректним, автори- } \\
\text { тарним. }\end{array}$ \\
\hline
\end{tabular}

Зазначене вище дозволило констатувати наступне: спроби сучасними педагогами модернізації методики викладання предметів освітньої галузі «Здоров’я та фізична культура» в інклюзивних класах $\epsilon$, однак вони фрагментарні, мають несистематизований формат. Більшість 3 них засновані на застарілих прийомах «розвішування ярликів», авторитарного підходу, штучного обмеження або примусу. Зазначені позиції вкрай суперечать принципам інклюзії, а також чинним вимогам до сучасного уроку. 


\section{4. Узгодженість мети, завдань Державного стандарту \\ і принципів інклюзивного навчання}

3 метою розробки матриці спільних навчальних завдань для учнів на уроках «Основи здоров'я» та «Фізична культура» ми виокремили певні ключові фрази з мети, завдань Державного стандарту базової і повної загальної середньої освіти [3] та принципів інклюзивного навчання [1] (рис. 1).

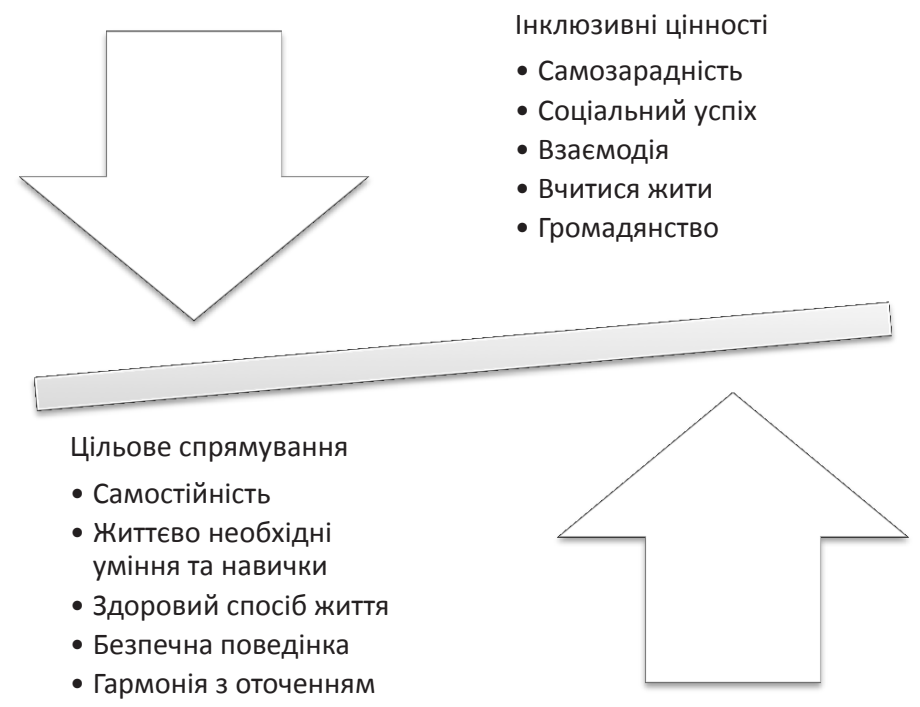

\section{Рис. 1. Узгодженість мети, завдань Державного стандарту і принципів інклюзивного навчання.}

При цьому орієнтувалися на такі принципи інклюзивного навчання:

- ніхто не залишається «за бортом»;

- ні - дискримінації; всім - рівний доступ, рівні права;

- має бути включення дітей в роботу на їхніх власних умовах;

- конструктивне спілкування - основа організації навчальної роботи учнів інклюзивних класів;

- розробка певного творчого продукту = унікальне ексклюзивне вирішення проблеми або ситуації самими учнями - індикатор ефективної навчальної діяльності педагога. 


\section{5. Зіставлення ключових фраз мети освітньої галузі і навчальних предме-тів}

Сучасному педагогу вкрай важливо мати інструментарій щодо організації навчального процесу відповідно до програмних вимог. Це стосується вимог до сучасного уроку, які зазначені в пояснювальній записці навчальної програми 3 предмета [11; 12]. Важливо також мобільно й потужно модернізувати урок відповідно до Концепції Нової української школи [13]. Тому наступним кроком нашого дослідження було зіставлення в єдину паралель ключових позицій мети освітньої галузі [3] та завдань навчальних предметів «Основи здоров'я» [11] i «Фізична культура» [12] (табл. 2).

Таблиця 2

Зіставлення ключових фраз мети освітньої галузі і навчальних предметів

\begin{tabular}{|c|c|c|c|c|}
\hline \multirow{3}{*}{ 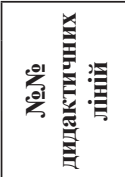 } & \multicolumn{3}{|c|}{ МЕТА - ЗАВДАННЯ - РЕЗУЛЬТАТ } & \multirow{3}{*}{$\begin{array}{c}\text { АЛГОРИТМ } \\
\text { ЩОДО РОЗРОБКИ } \\
\text { НАВЧАЛЬНИХ } \\
\text { ЗАВДАНЬ ДЛЯ УЧНІВ }\end{array}$} \\
\hline & \multirow{2}{*}{$\begin{array}{c}\text { ЦІЛЬОВЕ } \\
\text { СПРЯМУВАННЯ }\end{array}$} & \multicolumn{2}{|c|}{$\begin{array}{l}\text { ІНДИКАТОРИ ЕФЕКТИВНОЇ } \\
\text { НАВЧАЛЬНОЇ ДІЯЛЬНОСТІ }\end{array}$} & \\
\hline & & $\begin{array}{c}\text { ОСНОВИ } \\
\text { ЗДОРОВ'Я }\end{array}$ & $\begin{array}{c}\text { ФІЗИЧНА } \\
\text { КУЛЬТУРА }\end{array}$ & \\
\hline 1. & Самостійність & \begin{tabular}{|l|} 
Відповідаль- \\
ність за здоров'я
\end{tabular} & $\begin{array}{l}\begin{array}{l}\text { Світоглядні } \\
\text { орієнтири }\end{array} \\
\end{array}$ & \begin{tabular}{|l|} 
Створити умови для \\
розвитку самозарадності.
\end{tabular} \\
\hline 2. & $\begin{array}{l}\text { Життєво необ- } \\
\text { хідні уміння та } \\
\text { навички }\end{array}$ & $\begin{array}{l}\text { Усвідомлене } \\
\text { ставлення } \\
\text { до здоров'я, } \\
\text { самопізнання, } \\
\text { самовдоскона- } \\
\text { лення }\end{array}$ & $\begin{array}{l}\text { Функціональні } \\
\text { можливості }\end{array}$ & $\begin{array}{l}\text { Надати можливість } \\
\text { дитині стати соціально } \\
\text { успішною. }\end{array}$ \\
\hline 3. & $\begin{array}{l}\text { Здоровий спосіб } \\
\text { життя }\end{array}$ & $\begin{array}{l}\text { Здоров’язбе- } \\
\text { режу-вальна } \\
\text { компетентність }\end{array}$ & $\begin{array}{l}\text { Саморозвиток, } \\
\text { самонавчання }\end{array}$ & $\begin{array}{l}\text { Конструювати ситуа- } \\
\text { ції, які демонструють } \\
\text { позитивну перспективу } \\
\text { взаємодій учасників. }\end{array}$ \\
\hline 4. & $\begin{array}{l}\text { Безпечна пове- } \\
\text { дінка }\end{array}$ & \begin{tabular}{|l|} 
Відповідаль- \\
ність за безпеку, \\
навколишне \\
середовище та \\
стабільність у \\
майбутньому
\end{tabular} & $\begin{array}{l}\text { Екологічний } \\
\text { стиль } \\
\text { мислення і } \\
\text { поведінки }\end{array}$ & $\begin{array}{l}\text { Скласти прообраз наступ- } \\
\text { ної системи взаємодії } \\
\text { людей, де дитина вчиться } \\
\text { просити, учитися, вира- } \\
\text { жати й доносити свою } \\
\text { думку, інтереси, бажання, } \\
\text { потреби. }\end{array}$ \\
\hline 5. & $\begin{array}{l}\text { Гармонія з ото- } \\
\text { ченням }\end{array}$ & $\begin{array}{l}\text { Активна грома- } \\
\text { дянська позиція }\end{array}$ & \begin{tabular}{|l|} 
Загальна \\
культура, соці- \\
алізація
\end{tabular} & $\begin{array}{l}\text { Створити умови для } \\
\text { спілкування з одноліт- } \\
\text { ками та участі в громад- } \\
\text { ському житті класу. } \\
\end{array}$ \\
\hline & & & & ідал \\
\hline
\end{tabular}


Таким чином виокремили п'ять дидактичних ліній. Кожна лінія отримала назву за цільовим спрямуванням:

1) самостійність;

2) життєво необхідні уміння та навички;

3) здоровий спосіб життя;

4) безпечна поведінка;

5) гармонія $з$ оточенням.

Зауважимо, що вище зазначені дидактичні лінії подані не за рейтингом їх значення.

У межах кожної дидактичної лінії виокремлені ключові фрази із педагогічних завдань кожного предмета, які, у свою чергу, зіставлені із сутністю їі цільового спрямування. Таким чином були окреслені індикатори ефективної навчальної діяльності педагогів освітньої галузі.

3 опорою на мету завдання та принципи інклюзивного навчання подано алгоритм щодо розробки навчальних завдань для учнів інклюзивних класів.

\section{6. Гуманітарні технології - база для розробки навчальних завдань для учнів інклюзивних класів}

У процесі пошуку найбільш рентабельних технологій як базових для розробки навчальних завдань нашу увагу привернули гуманітарні технології, які використовують спеціалісти в умовах інклюзивної освіти.

Гуманітарні технології - це технології самовираження людей, самореалізації їхніх інтелектуальних якостей. Передбачають послідовні дії педагога щодо спеціального моделювання певних ситуацій, у вирішенні яких учасники (учні та педагоги) відпрацьовують навички спілкування, взаємодії, що, в свою чергу, посилює ефект навчання, виховання, розвитку [10].

Приймаючи переваги гуманітарних технологій; виокремили їх як профілактичні щодо усунення недоліків вузького використання певних методик, прийомів на уроках «Основи здоров’я», «Фізична культура» (рис. 2). 


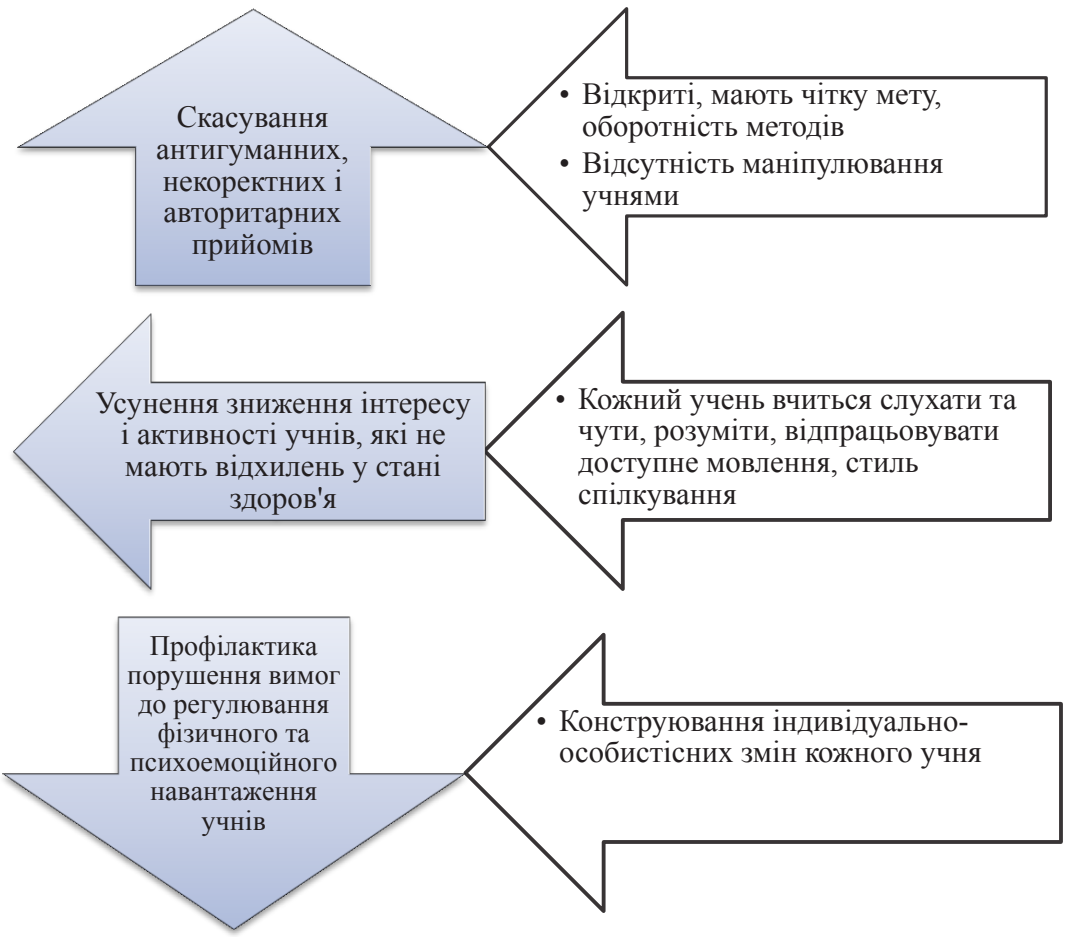

\section{Рис. 2. Переваги гуманітарних технологій у контексті усунення негативних наслідків вузького використання певних методик навчання}

\section{7. Матриця спільних навчальних завдань для учнів інклюзивних класів на уроках освітньої галузі «Здоров'я та фізична культура»}

Результати описаної вище дослідницької роботи дозволили скласти матрицю спільних навчальних завдань для учнів інклюзивних класів на уроках освітньої галузі «Здоров’я та фізична культура» (табл. 3).

Матриця спільних навчальних завдань для учнів інклюзивних класів структурована за такими складовими:

- лінія (п'ять дидактичних ліній, поява яких розкрита нами в табл. 2); 
Матриця спільних навчальних завдань для учнів інклюзивних класів на уроках освітньої галузі «Здоров'я та фізична культура»

\begin{tabular}{|c|c|c|c|}
\hline ЛІНІЯ & $\begin{array}{c}\text { ПЕРЕВАГИ ДЛЯ } \\
\text { УЧНІВ, ЯКІ } \\
\text { МАЮТЬ ООП }\end{array}$ & $\begin{array}{l}\text { АЛГОРИТМ } \\
\text { ЩОДО РОЗРОБКИ } \\
\text { СПІЛЬНИХ } \\
\text { НАВЧАЛЬНИХ } \\
\text { ЗАВДАНЬ ДЛЯ } \\
\text { УЧНІВ }\end{array}$ & $\begin{array}{c}\text { ПЕРЕВАГИ ДЛЯ } \\
\text { НЕЙРОТИПІЧНИХ } \\
\text { УЧНІВ }\end{array}$ \\
\hline 1 & 2 & 3 & 4 \\
\hline 1. Самостійність & $\begin{array}{l}\text { Усвідомлення необ- } \\
\text { хідності власного } \\
\text { вкладу в життя } \\
\text { суспільства }\end{array}$ & $\begin{array}{l}\text { Створити умови для } \\
\text { розвитку самозарад- } \\
\text { ності }\end{array}$ & $\begin{array}{l}\text { Зростання соціальної } \\
\text { свідомості, толерант- } \\
\text { ності }\end{array}$ \\
\hline $\begin{array}{l}\text { «ОСНОВИ } \\
\text { ЗДОРОВ’Я» }\end{array}$ & \multicolumn{3}{|c|}{$\begin{array}{l}\text { «АЛЬТЕРНАТИВА». Учні об’єднуються в групи. Кожна група учнів } \\
\text { отримує завдання - створити плакат «12 справ замість...». Учні мають } \\
\text { навести приклади негативного впливу людини на природу, та запропо- } \\
\text { нувати посильні для них справи, щоб перетворити навколишнє середо- } \\
\text { вище на екологічно та соціально безпечне. Кожна група презентує свої } \\
\text { напрацювання. }\end{array}$} \\
\hline \multicolumn{4}{|c|}{ Екологічна грамотність та здорове життя } \\
\hline $\begin{array}{l}\text { «ФЗИЧНА } \\
\text { КУЛЬТУРА» }\end{array}$ & \multicolumn{3}{|c|}{$\begin{array}{l}\text { «СВОЯ ЗВ'ЯЗКА, СВОЯ ГРА». Таке завдання передбачає опану- } \\
\text { вання учнями різними руховими діями, вправами з нестандартним } \\
\text { інвентарем (пакети, губки, картонні тарілки, хустки). Він безпечний } \\
\text { у використанні в будь-яких умовах, не летить і не котиться далеко, } \\
\text { доступний вдома. Після цього вчитель пропонує учням об'єднатися } \\
\text { у мікрогрупи (3-5 осіб). Обрати два види інвентарю на власний роз- } \\
\text { суд. В межах відведеного вчителем майданчика та часу учасникам } \\
\text { кожної мікрогрупи слід скласти правила та умови «спортивної гри», } \\
\text { дати їй назву, зіграти в неї. Презентувати своїм товаришам по класу. } \\
\text { Можливо, в подальшому, організувати та провести турнір з цієї гри зі } \\
\text { своїми молодшими товаришами в школі. }\end{array}$} \\
\hline $\begin{array}{l}\text { 2. Життєво необ- } \\
\text { хідні уміння та } \\
\text { навички }\end{array}$ & $\begin{array}{l}\text { Уміння ефективно } \\
\text { працювати в команді } \\
\text { та комунікувати в } \\
\text { різних середовищах }\end{array}$ & $\begin{array}{l}\text { Надати можливість } \\
\text { дитині стати соці- } \\
\text { ально успішною }\end{array}$ & $\begin{array}{l}\text { Розвиток навичок } \\
\text { співробітництва }\end{array}$ \\
\hline $\begin{array}{l}\text { «ОСОВИ } \\
\text { ЗДОРОВ’Я» }\end{array}$ & \multicolumn{3}{|c|}{$\begin{array}{l}\text { «КАЛОРИМЕТР». Учні об’єднуються у групи. Учитель пропонує } \\
\text { кожній групі скласти меню на сніданок, обід та вечерю із заздале- } \\
\text { гідь вказаною кількістю калорій. Якщо є можливість, то калорійність } \\
\text { продуктів для меню учні шукають за допомогою гаджетів, якщо - ні, } \\
\text { вчитель пропонує роздруківки з найпопулярнішими продуктами та } \\
\text { їх енергетичною цінністю. Учні презентують меню, аргументуючи } \\
\text { його раціональність. Потім складають індивідуальну тренувальну } \\
\text { програму щодо відпрацювання калорій засобами фізичних вправ. } \\
\text { Виконують свою програму на уроці чи вдома. }\end{array}$} \\
\hline
\end{tabular}


Features of use of flexible methods of teaching of students of inclusive...

Продовження таблиці 3

\begin{tabular}{|c|c|c|c|}
\hline 1 & 2 & 3 & 4 \\
\hline \multicolumn{4}{|c|}{ Уміння вчитися впродовж життя } \\
\hline $\begin{array}{l}\text { «ФІЗИЧНА } \\
\text { КУЛЬТУРА» }\end{array}$ & \multicolumn{3}{|c|}{$\begin{array}{l}\text { «TEAM RECORDS». Учні працюють у мікрогрупах. Учитель про- } \\
\text { понує декілька різновидів дрібного інвентарю спортивного чи побу- } \\
\text { тового характеру. Спочатку Лідери команд домовляються про кіль- } \\
\text { кість інвентарю, яку буде обирати кожний учасник команди. Потім } \\
\text { кожна команда домовляється, } 3 \text { яким саме інвентарем вони будуть } \\
\text { працювати. Після цього кожна команда обумовлює рухову дію, вико- } \\
\text { нує їі рекордну кількість разів. Складає показники всіх учасників. То } \\
\text { і буде командний рекорд. Подальша робота передбачає демонстра- } \\
\text { цію власної рухової дії іншим командам-учасницям. Також можна } \\
\text { запропонувати кожній команді обрати ту, чий рекорди вони спробу- } \\
\text { ють «побити». }\end{array}$} \\
\hline $\begin{array}{l}\text { 3. Здоровий спосіб } \\
\text { життя }\end{array}$ & $\begin{array}{l}\text { Формування здатно- } \\
\text { сті долати будь-які } \\
\text { бар'єри, які } є \text { перепо- } \\
\text { нами для повноцінної } \\
\text { життцдіяльності }\end{array}$ & $\begin{array}{l}\text { Конструювати ситуа- } \\
\text { ції, які демонструють } \\
\text { позитивну пер- } \\
\text { спективу взаємодій } \\
\text { учасників }\end{array}$ & $\begin{array}{l}\text { Усвідомлення від- } \\
\text { сутності різниць між } \\
\text { собою та іншими }\end{array}$ \\
\hline $\begin{array}{l}\text { «ОСНОВИ } \\
\text { ЗДОРОВ'Я» }\end{array}$ & \multicolumn{3}{|c|}{$\begin{array}{l}\text { «МИ - РІЗНІ, МИ - СХОЖІ». Учні об’єднуються в пари. Вчитель } \\
\text { пропонує записати } 5 \text { спільних рис, про які можна було б поговорити, } \\
\text { замість того, щоб сперечатися про відмінності. Вчитель має підвести } \\
\text { учнів до власного підсумку: щоб жити дружно, варто шукати те, що } \\
\text { зближує, а не роз'єднує [2]. }\end{array}$} \\
\hline \multicolumn{4}{|c|}{ Соиіальна та громадянська компетентності } \\
\hline $\begin{array}{l}\text { «ФІЗИЧНА } \\
\text { КУЛЬТУРА» }\end{array}$ & \multicolumn{3}{|c|}{$\begin{array}{l}\text { «ТРИМАЙ РЯД». Учасники об’єднуються в дві команди з рів- } \\
\text { ною кількістю представників. Шикуються в паралельні шеренги } \\
\text { на зручній відстані одна від іншої. Праворуч-ліворуч від кожної } \\
\text { шеренги учасників - конуси. Учасники першої шеренги почина- } \\
\text { ють виконувати певну вправу на розвиток фізичної якості. Їм слід } \\
\text { якомога швидше дійти синхронного способу виконання однакової } \\
\text { вправи. За ними починають повторювати (копіювати) учасники } \\
\text { другої шеренги. Після цього лунає команда вчителя «Перехід». } \\
\text { Це означає, що учасники другої шеренги в колоні переміщуються } \\
\text { за першим учасником навколо конусів попереду першої команди, } \\
\text { займають лідируючу позицію і стають замовниками наступної } \\
\text { вправи. Виконання ігрового завдання продовжується, доки виста- } \\
\text { чає довжини майданчику. }\end{array}$} \\
\hline $\begin{array}{l}\text { 4. Безпечна пове- } \\
\text { дінка }\end{array}$ & $\begin{array}{l}\text { Поява бажання покра- } \\
\text { щувати свої кондиції }\end{array}$ & \begin{tabular}{|l|} 
Скласти прообраз \\
такої системи взаємо- \\
дії людей, де дитина \\
вчиться просити, \\
учитися, виражати \\
й доносити свою \\
думку, інтереси, \\
бажання, потреби \\
\end{tabular} & $\begin{array}{l}\text { Розвиток самосвідо- } \\
\text { мості, самооцінки, } \\
\text { самовдосконалення }\end{array}$ \\
\hline
\end{tabular}


Закінчення таблиці 3

\begin{tabular}{|c|c|c|c|}
\hline 1 & 2 & 3 & 4 \\
\hline $\begin{array}{l}\text { «ОСНОВИ } \\
\text { ЗДОРОВ’Я» }\end{array}$ & \multicolumn{3}{|c|}{$\begin{array}{l}\text { «ОЗДОРОВЧІ СИСТЕМИ». Учні об’єднуються в групи. Учитель } \\
\text { пропонує опрацювати теоретичний матеріал щодо автора оздоровчої } \\
\text { системи та її спрямованості, виконати вправи. Потім на «станції» } \\
\text { залишається один представник групи - Тренер, який презентує цю } \\
\text { систему та її автора іншим учням. Інші учасники групи переміщу- } \\
\text { ються за стрілкою годинника на наступну «станцію». Потім знову від- } \\
\text { бувається зміна Тренера. Кількість переміщень відповідає кількості } \\
\text { станцій. }\end{array}$} \\
\hline \multicolumn{4}{|c|}{ Обізнаність та самовираження у сфері культури } \\
\hline $\begin{array}{l}\text { «ІЗИЧНА } \\
\text { КУЛЬТУРА» }\end{array}$ & \multicolumn{3}{|c|}{$\begin{array}{l}\text { «МЕТОДИЧНА ВЕРТУШКА». Учні об’єднуються в чотири мікро- } \\
\text { групи. Кожній мікрогрупі - власна зона активності. Лідери команд } \\
\text { обирають жеребкуванням назву інвентарю. Учасники команд мають } \\
\text { придумати одну вправу (складну та красиву) з обраним інвентарем, } \\
\text { виконувати ії до наступної команди учителя. Після команди «Шикуйсь! } \\
\text { Тренери вийшли зі строю» усі команди шикуються у своїй зоні актив- } \\
\text { ності, Тренери виходять із строю, залишаються на вихідній пози- } \\
\text { ції. Інші - переходять до наступної зони активності. Тренери мають } \\
\text { навчити своїй вправі нових учнів. Потім може відбуватися ще одна } \\
\text { ротація. Учитель може також додавати (шляхом жеребкування) певні } \\
\text { методичні вказівки. Наприклад, роздає картки з назвами фізичних яко- } \\
\text { стей. Це означає, що учасники команд мають додати до своєї першої } \\
\text { вправи певний елемент щодо розвитку зазначеної фізичної якості. }\end{array}$} \\
\hline $\begin{array}{l}\text { 5. Гармонія } 3 \\
\text { оточенням }\end{array}$ & $\begin{array}{l}\text { Поліпшення когнітив- } \\
\text { ного, моторного, мов- } \\
\text { ного, соціального та } \\
\text { емоційного розвитку, } \\
\text { бажання наслідувати } \\
\end{array}$ & $\begin{array}{l}\text { Створити умови для } \\
\text { спілкування з одно- } \\
\text { літками та участі у } \\
\text { громадському житті } \\
\text { класу (групи) } \\
\end{array}$ & $\begin{array}{l}\text { Розвиток навичок } \\
\text { діяти нестандартно, } \\
\text { бути винахідливими, } \\
\text { а також співчувати } \\
\text { іншим } \\
\end{array}$ \\
\hline $\begin{array}{l}\text { «ОСНОВИ } \\
\text { ЗДОРОВ’Я» }\end{array}$ & \multicolumn{3}{|c|}{$\begin{array}{l}\text { «СИНЕРГІЯ». Кожен учень отримує картку } 3 \text { назвою предмета і } \\
\text { придумує, як його можна використати, крім основного призначення. } \\
\text { Далі учні об’єднуються у пари. Вдвох учасники придумують, як } \\
\text { можуть між собою взаємодіяти їх предмети і що з них можна зробити. } \\
\text { Презентують новий винахід за обмежений час. Далі по } 2 \text { пари об’єд- } \\
\text { нуються між собою. Завдання аналогічне: об’єднати спосіб застосу- } \\
\text { вання чотирьох предметів і продемонструвати результат їхньої діяль- } \\
\text { ності [2]. }\end{array}$} \\
\hline \multicolumn{4}{|c|}{ Ініціативність і підприємливість } \\
\hline $\begin{array}{l}\text { «ФІЗИЧНА } \\
\text { КУЛЬТУРА» }\end{array}$ & \multicolumn{3}{|c|}{$\begin{array}{l}\text { «ЗМІНЮЙ ВИХІДНЕ ПОЛОЖЕННЯ ПОПЕРЕДНЬОГО ТОВА- } \\
\text { РИША». Учні об'єднуються в однакові за кількістю групи (5-7 осіб). } \\
\text { Учитель обумовлює вид шикування (коло, шеренга, колона тощо). } \\
\text { Після цього демонструє певне вихідне положення (асану), які мають } \\
\text { прийняти всі учасники. Далі ігрове завдання таке: наступний в строю } \\
\text { учасник кожної команди має змінити вихідне положення лише одним } \\
\text { рухом лише одніє частиною тулуба. Всі знову повторюють за другим } \\
\text { учасником. Гра триває до останнього учасника. }\end{array}$} \\
\hline
\end{tabular}


- переваги для учнів, які мають особливі освітні потреби (зазначені відповідно до кожної дидактичної лінії);

- переваги для нейротипічних учнів (зазначені відповідно до кожної дидактичної лінії, узгоджені зі змістом переваг для учнів, які мають особливі освітні потреби);

- алгоритм розробки спільних навчальних завдань для учнів (див. у тому числі табл. 2).

Формат матриці не передбачав додаткові структурні компоненти. Однак, для більш детального сприймання презентованого нами експериментального продукту до змісту таблиці 3 включили детальний опис навчальних завдань безпосередньо на уроках «Основи здоров'я» та «Фізична культура».

Ключовою рисою сучасності навчального закладу будь-якого типу є компетентнісний підхід до навчання його учнів. Не виключення й інклюзивні класи. За Концепцією Нової Української школи, компетентність - це сукупність особистісних якостей учня (умінь, цінностей, ставлення), «...зумовлених досвідом його діяльності в певній соціально й особистісно значущій сфері; здатність учня самостійно реалізовувати практичну діяльність і розв'язувати життєві проблеми, яка засновується на набутому навчальному та життєвому досвіді, особистісних цінностях і здібностях» [13]. Саме тому під час розробки спільних навчальних завдань ми орієнтувалися на вклад навчального предмета щодо формування зазначених навальною програмою ключових компетентностей учнів. У таблиці 3 ключові компетентності зазначені під кожним навчальним завданням для учнів.

\section{8. Методика визначення ефективності спільних навчальних завдань}

3 метою перевірки ефективності спільних навчальних завдань (відповідно до матриці) використано схему визначення коефіцієнта корисної дії навчального завдання (табл. 4).

Експериментальна апробація зазначеної схеми здійснювалася в межах дослідно-експериментальної роботи впродовж 2014-2017 рр. Загалом було проаналізовано 32 навчальних завдання на 16 уроках («Основи здоров'я» та «Фізична культура» по 8 кожний). Узагальнений результат - таблиця 5 


\section{Таблиця 4}

Схема визначення ККД навчального завдання учням на уроці

\begin{tabular}{|c|c|}
\hline $\begin{array}{c}\text { СПРЯМОВАНІСТЬ } \\
\text { ГРУПИ ПОКАЗНИКІВ }\end{array}$ & ЗМІСТ ПОКАЗНИКІВ ${ }^{1}$ \\
\hline $\begin{array}{l}\text { Які базові потреби учнів } \\
\text { задовольняли? }\left(5^{2}\right)\end{array}$ & \begin{tabular}{|l} 
1. У русі. \\
2. У безпеці. \\
3. У самоактуалізації. \\
4. У пізнанні та розумінні. \\
5. У визнанні та любові.
\end{tabular} \\
\hline $\begin{array}{l}\text { Які вимоги до сучасного } \\
\text { уроку реалізували? (5) }\end{array}$ & $\begin{array}{l}\text { 6. Забезпечення оптимізації навчально-виховного } \\
\text { проце-су із застосуванням елементів інноваційних } \\
\text { методів навчання та здійснення міжпредметних } \\
\text { зв’язків. } \\
\text { 7. Забезпечення освітньої, виховної, оздоровчої, } \\
\text { розвива-льної спрямованості навчального процесу. } \\
\text { 8. Формування в учнів умінь і навичок самостійно } \\
\text { займа-тися, вчитися. } \\
\text { 9. Використання вчителем різноманітних організа- } \\
\text { ційних форм, засобів, методів і прийомів навчання. } \\
\text { 10. Досягнення оптимальної рухової активності } \\
\text { всіх учнів на кожному уроці з урахуванням стану } \\
\text { здоров’я. }\end{array}$ \\
\hline $\begin{array}{l}\text { Як накопичувався індекс } \\
\text { здоров'я уроку? (7) }\end{array}$ & $\begin{array}{l}\text { 11. Повага до здатності кожного учня бути самодо- } \\
\text { стат-ньою особистістю. } \\
\text { 12. 90\% моторна щільність. } \\
\text { 13. Вчителя було мало. } \\
\text { 14. Не закріплювали вміння та навички. } \\
\text { 15. Створювали умови для збагачення досвіду учнів. } \\
\text { 16. Розвивали емоційний інтелект учнів. } \\
\text { 17. Учнів не поділяли, а поєднували в динамічні } \\
\text { довільні групи. }\end{array}$ \\
\hline \multicolumn{2}{|r|}{ PIBHI. КРИТЕРIÏ } \\
\hline Високий рівень & Більше 15 \\
\hline Середній рівень & $7-14$ \\
\hline Критичний рівень & Менше 6 \\
\hline
\end{tabular}

${ }^{1}$ За кожну позицію виставляється 1 бал в разі іiі наявності.

2 Загальна кількість позицій в кожній групі показників.

Виокремлені чинники, які знижували ККД навчальних завдань (табл. 6). Частотність виявлення визначалася за формулою 1 :

$$
x=100-\frac{N o z+N f c}{2}
$$


Таблиця 5

Узагальнений результат визначення ККД навчальних завдань

для учнів інклюзивних класів на уроках «Основи здоров'я»

та «Фізична культура»

\begin{tabular}{|l|c|c|}
\hline \multicolumn{1}{|c|}{ ПОКАЗНИкИ } & $\begin{array}{c}\text { ОСНОВИ } \\
\text { ЗДОРОВ'Я, \% }\end{array}$ & $\begin{array}{c}\text { ФІЗИЧНА } \\
\text { КУЛЬУРА, \% }\end{array}$ \\
\hline К-сть навчальних завдань & 16 & 16 \\
\hline 1. В русі. & 25 & 56 \\
\hline 2. У безпеці. & 93,75 & 81,25 \\
\hline 3. У самоактуалізації. & 81,25 & 75 \\
\hline 4. У пізнанні та розумінні. & 68,75 & 62,5 \\
\hline 5. У визнанні та любові. & 81,25 & 75 \\
\hline $\begin{array}{l}\text { 6. Забезпечення оптимізації навчально-ви- } \\
\text { ховного процесу із застосуванням елементів } \\
\text { інноваційних методів навчання та здійснення } \\
\text { міжпредметних зв'язків. }\end{array}$ & 93,75 & 81,25 \\
\hline $\begin{array}{l}\text { 7. Забезпечення освітньої, виховної, оздоро- } \\
\text { вчої, розвивальної спрямованості навчаль- } \\
\text { ного процесу. }\end{array}$ & 68,75 & 56 \\
\hline $\begin{array}{l}\text { 8. Формування в учнів умінь і навичок само- } \\
\text { стійно займатися, вчитися. }\end{array}$ & 81,25 & 50 \\
\hline $\begin{array}{l}\text { 9. Використання вчителем різноманітних } \\
\text { організаційних форм, засобів, методів і при- } \\
\text { йомів навчання. }\end{array}$ & 100 & 100 \\
\hline $\begin{array}{l}\text { 10. Досягнення оптимальної рухової актив- } \\
\text { ності всіх учнів протягом кожного уроку з } \\
\text { урахуванням стану здоров'я. }\end{array}$ & 3,75 & 75 \\
\hline $\begin{array}{l}\text { 11. Повага до здатності кожного учня бути } \\
\text { самодостатньою особистістю. }\end{array}$ & 68,75 & 62,5 \\
\hline 12. 90\% моторна щільність. & 62,5 & 43,75 \\
\hline \begin{tabular}{l} 
13. Вчителя було мало. \\
\hline 14. Не закріплювали вміння та навички.
\end{tabular} & 81,25 & 73,75 \\
\hline $\begin{array}{l}\text { 15. Створювали умови для збагачення дос- } \\
\text { віду учнів. }\end{array}$ & 81,25 & 75 \\
\hline 16. Розвивали емоційний інтелект учнів. & 75 & 56 \\
\hline $\begin{array}{l}\text { 17. Учнів не поділяли, а поєднували в дина- } \\
\text { мічні довільні групи }\end{array}$ & 93,75 & 81,25 \\
\hline
\end{tabular}

де 100 - ідеальний результат за показники певної групи або усієї схеми;

Noz - фактичний результат за показники певної групи або усієї схеми за предметом «Основи здоров'я»; 


\begin{tabular}{|c|c|}
\hline \multicolumn{2}{|c|}{$\begin{array}{c}\text { Чинники педагогічної діяльності, які знижували ККД } \\
\text { навчальних завдань учням інклюзивних класів }\end{array}$} \\
\hline ЧИННИКИ, ЯКІ ЗНИЖУВАЛИ ККД & $\begin{array}{l}\text { ЧАСТОТНІСТЬ } \\
\text { ВИЯВЛЕННЯ, \% }\end{array}$ \\
\hline Периа група: задоволення базових потреб учнів (сер.) & 23,73 \\
\hline $\begin{array}{l}\text { Учні не отримують можливості рухатися так, як вони вміють / } \\
\text { бажають }\left(1^{1}\right)\end{array}$ & 59,5 \\
\hline $\begin{array}{l}\text { Учитель не помічає учнів у підгрупах, які соромляться зізна- } \\
\text { тися, що щось не зрозуміли або не вміють виконувати (4) }\end{array}$ & 34,37 \\
\hline $\begin{array}{l}\text { Учитель використовує індиферентні або безіменні фрази } \\
\text { похвали. Не зазначає, за що саме і кого хвалить (5) }\end{array}$ & 21,87 \\
\hline $\begin{array}{l}\text { Учитель сам призначає лідерів у групі, розподіляє функції } \\
\text { учням (3) }\end{array}$ & 21,87 \\
\hline $\begin{array}{l}\text { Порушуються вимоги безпечної роботи, особливо коли учитель } \\
\text { зосереджується на великій кількості різного роздаткового } \\
\text { інвентарю (2) }\end{array}$ & 12,5 \\
\hline Реалізація вимог до сучасного уроку (сер.) & 29,08 \\
\hline $\begin{array}{l}\text { Сувора регламентація рухових дій, безвідносна до адаптаційних } \\
\text { можливостей організму учнів. Використання вчителем простих } \\
\text { стереотипних рухів у дзеркальному відтворенні учнями (10) }\end{array}$ & 60,62 \\
\hline $\begin{array}{l}\text { Використання вчителем розчленованих завдань в простих } \\
\text { умовах виконання (7) }\end{array}$ & 37,62 \\
\hline $\begin{array}{l}\text { Учитель обумовлює повністю регламент дій учнів без можливої } \\
\text { ініціативи з їхнього боку (8) }\end{array}$ & 34,37 \\
\hline $\begin{array}{l}\text { Недоцільність використання певних інновацій, нераціональні } \\
\text { витрати часу (6) }\end{array}$ & 12,79 \\
\hline Учитель використовує різні форми, засоби, методи, прийоми (9) & 0 \\
\hline Накопичення індексу здоров'я уроку (сер.) & 25,26 \\
\hline $\begin{array}{l}\text { Учні багато часу слухають пояснення вчителя, чекають черги } \\
\text { щодо виконання завдання, дивляться на екран, дошку (12) }\end{array}$ & 46,87 \\
\hline Учитель багато часу витр0ачає на вербальні інструкції (13) & 46,87 \\
\hline $\begin{array}{l}\text { Деякі завдання не містять варіантів вибору учнем власної стра- } \\
\text { тегії або обсягу роботи (11) }\end{array}$ & 34,37 \\
\hline $\begin{array}{l}\text { Деякі завдання не передбачають можливості допомагати своїм } \\
\text { товаришам по команді або іншим учасникам (16) }\end{array}$ & 34,5 \\
\hline $\begin{array}{l}\text { Учитель пропонує вправу, виконання якої здійснюється в умо- } \\
\text { вах багаторазового повторення до автоматизму (14) }\end{array}$ & 21,87 \\
\hline $\begin{array}{l}\text { Учитель диктує темп, ритм, зміст, структуру завдання, пропо- } \\
\text { нує повторювати, копіювати певні дії (15) }\end{array}$ & 21,87 \\
\hline $\begin{array}{l}\text { Групи учнів формуються авторитарним способом на розсуд } \\
\text { учителя (17) }\end{array}$ & 12,5 \\
\hline
\end{tabular}

${ }^{1}$ Показник у схемі 
$\mathrm{Nfc}$ - фактичний результат за показники певної групи або усієї схеми за предметом «Фізична культура»;

$\mathrm{X}$ - чинник, який знижує ККД (навчального завдання або усього уроку).

Таким чином були визначені найбільш вагомі чинники педагогічної дія-льності, які знижували ККД навчального завдання, отже - й самого уроку. Зокрема:

I. За першою групою «Задоволення базових потреб учнів» / Учні не мають можливості виконувати завдання за власною схемою.

II. За другою групою «Реалізація вимог до сучасного уроку» / Сувора регламентація рухових дій, безвідносна до адаптаційних можливостей організму учнів. Використання вчителем простих стереотипних рухів у дзеркальному відтворенні учнями.

III. За третьою групою «Накопичення індексу здоров'я уроку» / Учні багато часу слухають пояснення вчителя, чекають черги щодо виконання завдання, дивляться на екран, дошку.

Однак, поряд із зазначеними чинниками, які знижують ККД завдання або уроку, відмічені позитивні ефекти під час роботи учнів над виконання завдань:

1) під час об’єднання учнів у мікрогрупи за умов рівної кількості учасників жодна особа не обирала найсильнішого, найрозумнішого; учні намагалися якнайшвидше сформувати команду, керуючись лише кількісними показниками та зручністю переміщення й розташування;

2) усі учні демонстрували високий рівень соціальної активності;

3) під час роботи у групах більшість учнів звертала увагу на особистість, а не на ваду, демонструючи високий рівень соціальної взаємодії;

4) під час групової роботи учасники намагалися надати підтримку один одному;

5) учні та педагог не шукали помилок під час виконання певних завдань; вони піклувалися про найкращий спільний результат роботи своєї групи;

6) дуже швидко здійснювався розподіл функцій між учасниками групи, особливо коли в це не втручався педагог;

7) формат діяльності «очі в очі» посилював індекс поваги та толерантності в учнівській групі. 


\section{9. Висновки з проведеного дослідження}

Здійснене дослідження дозволило констатувати наступне:

- спроби сучасними педагогами модернізації методики викладання предметів освітньої галузі «Здоров'я та фізична культура» в інклюзивних класах фрагментарні, мають несистематизований формат. Більшість 3 них засновані на застарілих прийомах «розвішування ярликів», авторитарного підходу, штучного обмеження або примусу;

- аналіз завдань із навчальних програм предметів «Основи здоров'я», «Фізична культура», зіставлення їх сутнісного спрямування 3 принципами інклюзивного навчання дозволили розробити матрицю спільних навчальних завдань для учнів інклюзивних класів;

- експериментальна апробація навчальних завдань надала можливість визначити їх високий коефіцієнт корисної дії не лише в умовах інклюзивного навчання, а й у звичайних класах.

Перспективи використання результатів дослідження полягають у адаптації матриці спільних навчальних завдань до предметів інших освітніх галузей; проведенні відповідних навчальних тренінгів для педагогів, які працюють в інклюзивних класах.

\section{Список літератури:}

1. Бут Тоні Індекс інклюзії: розвиток навчання та участі в життєдіяльності шкіл: посібник / Тоні Бут; пер. $з$ англ. - К.: ТОВ Видавничий дім «Плеяди», 2015. - $190 \mathrm{c}$.

2. Воронцова Т. В. Вчимося жити разом. Посібник для вчителя з розвитку соціальних нави-чок у курсі «Основи здоров'я» (основна і старша школа) / Т. В. Воронцова, В. С. Пономаренко - К.: Вид-во «Алатон», 2016. - 232 с.

3. Державний стандарт базової і повної загальної середньої освіти [Електронний ресурс] // Законодавство України: [сайт]. - Режим доступу: http://zakon2.rada.gov.ua/laws/show/1392-2011-\%D0\%BF, вільний. - Назва 3 екрана. - (Дата звернення: 05.03.2018).

4. Інклюзивна освіта в Україні: здобутки, проблеми та перспективи. Резюме аналітичного звіту за результатами комплексного дослідження / ERA Європейська дослідницька ор-ганізація. - Червень 2011 - січень 2012. - 36 с.

5. Інклюзивна освіта: основні положення [Електронний ресурс] / Всеукраїнський фонд «Крок за кроком»: [сайт]. - Режим доступу: http://www.ussf.kiev.ua/ ie_inclusive_education/, вільний. - Назва з екрана. - (Дата звернення: 05.03.2018).

6. Кетриш Е. В. О проблеме инклюзивного образования в сфере физической культуры / Е. В. Кетриш // Сибирский педагогический журнал. № 3. - 2015. - С. 121-124. - То же [Электронный ресурс]. - Режим доступа: https://cyberleninka.ru/article/v/o-probleme-inklyuzivnogo-obrazovaniya-v-sferefizicheskoy-kultury, свободный. - Название с экрана. - (Дата обращения: 24.02.2018). 


\section{Features of use of flexible methods of teaching of students of inclusive...}

7. Кожокару Пол 3С терапия / Пол Кожокару // 3C THERAPIA психомоторное развитие для людей с аутизмом : [сайт]. - Режим доступа: http://www.sportautism.ro/terapia-3c/, свободный. - Название с экрана. - (Дата обращения: 04.03.2018).

8. Кожокару Пол О 3C терапии - цели / Пол Кожокару // 3C THERAPIA : [сайт]. - Режим доступа: http://paul-cojocaru.blogspot.ro/search?updated-max= 2016-01-27T08:32:00\%2B02:00\&max-results=7\&start=34\&by-date=false/, свободный. - Название с экрана. - (Дата обращения: 24.02.2018).

9. Метод реальной инклюзии // Центр реальной инклюзии «Эрудит» : [сайт]. - Режим дос-тупа: http://erudit-inclusion.com/, свободный. - Название с экрана. - (Дата обращения: 24.02.2018).

10. Митин А. Е. Гуманитарные технологии: обоснование основних положений применения в образовании / А. Е. Митин., С. О. Филиппова // Знание, понимание, умение. - 2013.- № 3.- С. 255-262. - То же [Электронный ресурс]. Режим доступа: http://www.zpu-journal.ru/zpu/contents/2013/3/Mitin_FilippovaHumanitarian-Technologies/40_2013_3.pdf, сво-бодный. - Название с экрана. (Дата обращения: 03.03.02018).

11. Навчальна програма 3 основ здоров'я для 5-9-х класів загальноосвітніх навчальних за-кладів затверджена наказом МОН від 07.06.2017 № 804 [Електронний ресурс] / Т. Є. Бойченко, Т. В. Воронцова та ін. - Режим доступу: https://osvita.ua/school/program/program-5-9/56137/, вільний. - Назва з екрана. - (Дата звер-нення: 05.03.2018).

12. Навчальна програма з фізичної культури для 5-9 класів загальноосвітніх навчальних за-кладів. (затверджена наказом МОН від 23.10.2017 № 1407) [Електронний ресурс] / Гол. роб. групи Т. Ю. Круцевич // Міністерство освіти і науки України : [сайт]. - Режим доступу: https://mon.gov.ua/ua/osvita/zagalnaserednya-osvita/navchalni-programi/navchalni-programi-5-9-klas, вільний. Назва з екрана. - (Дата звернення: 05.03.2018).

13. Нова українська школа. Концептуальні засади реформування середньої школи [Електронний ресурс]. - Режим доступу: https://www.kmu.gov.ua/ storage/app/media/reforms/ukrainska-shkola-compressed.pdf, вільний. Назва 3 екрана. - (Дата звернення: 05.11.2017).

14. Палий Л. Инклюзивные подходы в обучении на уроках физкультуры [Электронный ре-сурс] / Л. Палий // Учительская газета: [сайт]. - Режим доступа: http://www.ug.ru/method article/1074, свободный. - Название с

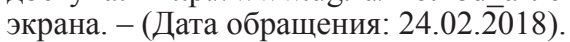

\section{References:}

1. But Toni (2015) Indeks inkliuzii: rozvytok navchannia ta uchasti v zhyttiediialnosti shkil: posibnyk [Inclusion Index: Development of Learning and Participation in School Life: Manual]. Kyiv: Pleiady. (in Ukrainian)

2. Vorontsova T. V., Ponomarenko V. S. (2016) Vchymosia zhyty razom. Posibnyk dlia vchytelia z rozvytku sotsialnykh navychok u kursi "Osnovy zdorovia" (osnovna $i$ starsha shkola) [Let's live together. Teacher's Guide to Social Skills Development in the Course "Health Basics" (secondary and high school)]. Kyiv: Alaton. (in Ukrainian)

3. Zakonodavstvo Ukrainy (2011) Derzhavnyi standart bazovoi $i$ povnoi zahalnoi serednoi osvity [State Standard for Basic and Comprehensive Secondary 


\section{Aksyonova Olena, Pivnenko Yuliya}

Education]. Retrieved from: http://zakon2.rada.gov.ua/laws/show/1392-2011$\%$ D0\%BF (accessed 05 March 2018).

4. Vseukrainskyi fond "Krok za krokom" Inkliuzyvna osvita: osnovni polozhennia [Inclusive Edu-cation: key statements]. Retrieved from: http:/www.ussf.kiev.ua/ ie inclusive education/ (accessed 05 March 2018).

5. Ketrish E. V. (2015) O probleme inklyuzivnogo obrazovaniya $v$ sfere fizicheskoy kul'tury [About the problem of inclusive education in the field of Physical Education]. Siberian pedagogical journal, no. 3, pp. 121-124.

6. Kozhokaru Pol (2012) 3C terapiya [3C Therapy]. 3C THERAPIA - psikhomotornoe razvitie dlya lyudey $s$ autizmom [3C THERAPY - psychomotor development for people with autism] (site). Re-trieved from: http://www.sportautism.ro/ terapia-3c/ (accessed 05 March 2018).

7. Kozhokaru Pol (2014) O 3C terapii - tseli [About 3C Therapy - Goals]. $3 C$ terapiya [3C therapy] (site). Retrieved from: http://paul-cojocaru.blogspot.ro/ search?updated-max=2016-01-27T08:32:00\%2B02:00\&max-results=7\&start=34 \&by-date=false, (accessed 05 March 2018).

8. Tsentr real'noy inklyuzii "Erudit" (2015) Metod real'noy inklyuzii [The Real Method Of Inclu-sion]. Retrieved from: http:/erudit-inclusion.com/ (accessed 02 March 2018).

9. Mitin A. E., Filippova S. O. (2013) Gumanitarnye tekhnologii: obosnovanie osnovnikh polozheniy primeneniya v obrazovanii [Humanitarian technologies: substantiation of the main provisions of application in education]. Knowledge, understanding, skill, no. 3, pp. 255-262.

10. Boichenko T. Ye., Vorontsova T. V. (2017) Navchalna prohrama z osnov zdorovia dlia 5-9-kh klasiv zahalnoosvitnikh navchalnykh zakladiv [Education program of Health Basics for the 5-9 years of studies of general education institutions]. Retrieved from: https://osvita.ua/school/program/program-5-9/56137/ (accessed 02 March 2018).

11. Krutsevych T. Yu. (2017) Navchalna prohrama z fizychnoi kultury dlia 5-9 klasiv zahalnoosvit-nikh navchalnykh zakladiv [The curriculum on physical culture for 5-9 years of studies of general education institutions]. Retrieved from: https://mon.gov.ua/ua/osvita/zagalna-serednya-osvita/navchalni-programi/ navchalni-programi-5-9-klas (accessed 02 March 2018).

12. Ministerstvo osvity i nauky Ukrainy (2016) Nova ukrainska shkola. Kontseptualni zasady re-formuvannia serednoi shkoly [New Ukrainian School. Conceptual foundations of the reforms for the secondary school]. Retrieved from: https://www.kmu.gov.ua/storage/app/media/reforms/ukrainska-shkola-compressed.pdf (accessed 02 March 2018).

13. Paliy L. (2016) Inklyuzivnye podkhody v obuchenii na urokakh fizkul'tury [Inclusive approaches to teaching at physical education classes]. Teacher's Newspaper, 20 March 2016. Retrieved from: http://www.ug.ru/method_article/1074 (accessed 02 March 2018).

14. ERA - Yevropeiska doslidnytska orhanizatsiia: Demokratychni initsiatyvy molodi (2012) Ink-liuzyvna osvita v Ukraini: zdobutky, problemy ta perspektyvy. Reziume analitychnoho zvitu za re-zultatamy kompleksnoho doslidzhennia [Inclusive education in Ukraine: achievements, problems and prospects. Summary of analytical report based on the results of integrated research]. 